\title{
Fasciola Hepatica Infection as a Cause of Severe Hypereosinophilia
}

\section{Şiddetli Hipereozinofilinin Nedeni Olarak Fasciola Hepatika Enfeksiyonu}

\author{
Meriç Kaymak Cihan², Cahit Babür², Lale Olcay1 \\ ${ }^{1}$ Dr. Abdurrahman Yurtaslan Ankara Oncology Training and Research Hospital Department of Pediatric Hematology, Ankara, Turkey \\ 2Ankara Refik Saydam Hygiene Institute, Directorate of Epidemics Research Parasitological Laboratory, Ankara, Turkey
}

\section{To the Editor,}

Eosinophilia is considered as severe at levels of $>5 \times 109 / \mathrm{L}$ [1]. In childhood, the causes of severe eosinophilia are parasitic infections (visceral larva migrans, trichinosis, hookworm diseases, ascariasis, strongyloidiasis, fascioliasis), allergic disorders, malignant diseases (eosinophilic leukemia, Hodgkin disease, hypereosinophilic syndromes), and some collagen tissue diseases [2].

A boy from a rural area of Turkey, aged 6 years and 10 months, was admitted to our clinic with abdominal pain and severe hypereosinophilia. He had lately developed abdominal pain at the umbilical area, waxing and waning in character. His physical examination was unremarkable.

His laboratory tests are presented in Table 1.

Since no blast was found in the peripheral blood smear of the patient, secondary causes of hypereosinophilia were investigated. Multiple tests for parasitic infections and collagen tissue disorders were performed (Table 1). Tests for Echinococcus granulosus indirect hemagglutination (IHA) $(1 / 320$; normal: <1/160) and Fasciola hepatica IHA (1/5120; normal: $<1 / 160)$ were positive. A hypodense lesion of $6 \times 4 \mathrm{~cm}$ was found in the left lobe of the liver upon computed tomography and ultrasonography. Until the Echinococcus granulosus-specific IgE test was revealed to be negative, the patient was given 2 doses of albendazole at 15 mg/kg/day. After 2 weeks, IHA tests for Fasciola hepatica and
Echinococcus granulosus were repeated, which were again positive at $1 / 5120$ (normal: <1/160) and $1 / 320$ (normal: $1 / 160$ ), respectively. The mildly high Echinococcus granulosus IHA was considered to be a cross-reaction with Fasciola hepatica. The parents reported that they had been consuming spring water. For treatment of Fasciola hepatica infection, the patient was given 2 doses of triclabendazole at $10 \mathrm{mg} / \mathrm{kg} / \mathrm{dose}, 1$ week apart. The eosinophil counts 1 and 4 months following the second dose declined to $0.64 \times 109 / \mathrm{L}(7.8 \%)$ and $0.468 \times 109 / \mathrm{L}(4 \%)$, respectively, with no symptoms.

Fasciola hepatica, a liver fluke, is observed in areas of sheep farming and is common in developing countries [3]. More than 180 million people are at risk of Fasciola hepatica infection and 2.4 million people are already infected with this parasite [4]. Eosinophilia is encountered in 14\%-82\% of patients and may wax and wane during the chronic stage $[5,6]$.

In fascioliasis, liver lesions may be present and bile ducts may be observed as thickened and dilated in tomography $[7,8]$. Fasciola hepatica eggs in stool are generally observed in the acute phase but not in the chronic phase [6]. Serological tests including enzyme-linked immunosorbent assay (ELISA), IHA, complement-fixation, immunofluorescence, counter electrophoresis, and double diffusion are in use. However, all of these sensitive methods may still yield cross-reaction in parasitic infections like Echinococcus [7].

Address for Correspondence: Meriç Kaymak Cihan, M.D.

Dr. Abdurrahman Yurtaslan Ankara Oncology Training and Research Hospital Department of Pediatric Hematology, ankara, Turkey

Gsm: +90 31233609 09/7448 E-mail: cigdemusul@yahoo.com

Received/Geliş tarihi : February 5, 2012

Accepted/Kabul tarihi : November 14, 2012 
Table 1: Laboratory test results of the patient.

\section{Tests}

Complete Blood Count

Peripheral Blood Smear

$\operatorname{IgA} / \operatorname{Ig} M / \operatorname{Ig} G$

$\operatorname{IgE}$

Toxocara IgG

Toxoplasma IgM / IgG

Sabin-Feldman Dye Test

Leishmania IgM / IgG

Echinococcus granulosus indirect

hemagglutination (IHA)

Fasciola hepatica IHA

Echinococcus granulosus-specific IgE

Direct Coombs Test / Indirect Coombs Test

Collagen Tissue Disease Markers

Abdominal Ultrasonography

Abdominal Computed Tomography

Stool Examination, 5 Times

Anal Band Test

\section{Results}

White blood cells: 36,920 × 109/L; hemoglobin: $143 \mathrm{~g} / \mathrm{L}$; platelet count: $397 \times$ 109/L

$11 \%$ polymorphonuclear leucocytes, $66 \%$ eosinophils, $5 \%$ eosinophilic bands, $17 \%$ lymphocytes, and 1\% neutrophilic bands; eosinophil count yielding 23,840 × 109/L

81.4 mg/dL (normal: 70-303) / 223 mg/dL (normal: 69-387) / 1650 mg/dL

(normal: 764-2134)

$4328 \mathrm{kU} / \mathrm{L}$ (normal: 0-100 kU/L)

Negative

Negative / Negative

Negative

Negative / Negative

$1 / 320$ ( normal: $<1 / 160)$

$1 / 5120$ (normal: $<1 / 160)$

Negative

Negative / Positive

Negative

Hepatomegaly and a hypoechoic area of $46 \times 33 \mathrm{~mm}$ in size without regular contours observed in left lobe of liver

Hypodense lesion of $6 \times 4 \mathrm{~cm}$ observed in left lobe of liver along with dilatation of in trahepatic bile ducts at lateral segment of left lobe of liver

Negative

Negative
For treatment of Fasciola, 2 doses of triclabendazole, at 10 $\mathrm{mg} / \mathrm{kg} /$ dose 1 week apart, are recommended [6] .

Fascioliasis develops by the taking in of metacercarial cysts through consumption of aquatic plants (watercress in particular), or of contaminated water like in our case [6]. Fascioliasis can be prevented by taking hygienic precautions. Prognosis is excellent with appropriate treatment.

Long-duration and repetitive antigen exposure to T lymphocytes by parasites gives rise to excess production of interleukin (IL)-5, IL-4, and IL-13 by the T cells, which stimulates proliferation and survival of eosinophils [9].
Our case highlights that in severe eosinophilia, fascioliasis must also be considered, particularly when patients are from rural sheepbreeding areas and drink spring water.

\section{Conflict of Interest Statement}

The authors of this paper have no conflicts of interest, including specific financial interests, relationships, and/ or affiliations relevant to the subject matter or materials included.

\section{References}

1. Roufosse F, Weller PF. Practical approach to the patient with hypereosinophilia. J Allergy Clin Immunol 2010;1:39-44. 
2. Wagelie-Steffen A, Aceves SS. Eosinophilic disorders in children. Curr Allergy Asthma Rep 2006;6:475-482.

3. Adel AFM. Trematodes and Other Flukes. In: Mandell GL, Bennet JE, Dolin R (eds). Principles and Practice of Infectious Diseases, 5th ed. Philadelphia, Churchill Livingstone, 2000; 2954-2956.

4. World Health Organization. Risk Control of Foodborne Trematode Infection. WHO Technical Series No. 849. Geneva, WHO, 1995: 157.

5. el-Shabrawi M, el-Karaksy H, Okasha S, el-Hennawy A. Human fascioliasis: clinical features and diagnostic difficulties in Egyptian children. J Trop Pediatr 1997;43:162-166.
6. Fried B, Abruzzi A. Food-borne trematode infections of humans in the United States of America. Parasitol Res 2010;106:1263-1280.

7. Noyer CM, Coyle CM, Werner C, Dupouy-Camet J, Tanowitz HB, Wiitner M. Hypereosinophilia and liver mass in an immigrant. Am J Trop Med Hyg 2002;66:774-776.

8. Demirci M, Korkmaz M, Kaya S, Kuman A. Fascioliasis in eosinophilic patients in the Isparta region of Turkey. Infection 2003;31:15-18.

9. Lampinen M, Carlson M, Hakansson LD, Venge P. Cytokineregulated accumulation of eosinophils in inflammatory disease. Allergy 2004;59:793-805.. 